across a fault which cuts the Pre-Cambrian basement of the Derby-Loughborough district and possibly has a north-westerly strike. Since present non-instrumental evidence suggests that the epicentre lies at or near Diseworth, but affords no indication of a likely depth for the focus, the main quake, and perhaps its after-shock of February 12, may have resulted from motion across a deep continuation of either the Breedon Fault or the Normanton Hills Fault ${ }^{12}$, or possibly a third fault which lies between them, completely hidden beneath Triassic deposits.

The Breedon Fault, which occurs about three miles west of Diseworth, strikes between N. $318^{\circ} \mathrm{E}$. and N. $344^{\circ} \mathrm{E}$., and is known to cut Millstone Grit, but not the overlapping Triassic sediments. On the other hand, the Normanton Hills Fault, lying some two miles north of Diseworth, appears to strike about N. $292^{\circ} \mathrm{E}$. and cuts Lower Lias shales and limestones where it is exposed. This dislocation is believed to continue for a considerable distance to the east. However, it is equally likely that this quake and its after-shock were due to movements across a dislocation in the ancient basement which does not cut the overlying younger rocks at all.
The main quake was recorded on the seismographs at Durham, Cambridge, South Kensington, Kew, Dorking and Dublin, but apparently not in readable form at Aberdeen, Edinburgh or Bidston. From preliminary studies of available seismograms, Mr. E. Tillotson suggests an epicentre at $52^{\circ} 52^{\prime} \mathrm{N}$., $01^{\circ} 21^{\prime}$ W., that is, about 7.5 miles north-east of Ashby-dela-Zouch, and an initial time of $15 \mathrm{~h} .43 \mathrm{~m}$. $00 \mathrm{~s}$. at a focus perhaps six to eight miles below the surface.

' Dollar, A. T. J., Trans. Geol. Soc. Glasg., 21 (2), 285 (1951).

${ }^{2}$ Davison, C., Phil. Mag., 50, 51 (1900).

${ }^{3}$ Wood, H. O., and Newmann, F., Bull. Seismol. Soc. Amer., 21 , 277 (1931).

"Davison, C., Geol. Mag., 7, 412 (1910).

"Davison, C., "A History of British Earthquakes", 333 (Cambridge, 1924).

${ }^{6}$ Dollar, A. T. J., Trans Geol. Soc., Glasg., 21 (2), 312 (1951).

" Davison, C. " A History of British Earthquakes", 331-37 (Ca mbridge, 1924).

${ }^{8}$ Tillotson, E., Nature, 17\%, 165 (1956).

'Tillotson, E., idem.

10 Davison, C., "A History of British Earthquakes", 390 (Cambridge, 1924).

${ }^{11}$ Dollar, A. T. J., Trans. Geol. Soc. Glasg., 21 (2), 292 (1951).

${ }_{12}$ The Geology of the Country between Derby, Burton-on-Trent, Ashby-de-la-Zouch and Loughborough. Mem. Geol. Surv. U.K., 45, 48 (1905).

\title{
OBITUARIES
}

\section{Dr. J. von Neumann}

JoHN VON NEUMANN was a remarkable man. Probably the most important of all his qualities were the accuracy and speed of his thinking, whether in a difficult mathematical argument or on a major policy point affecting the allocation of enormous research resources. Primarily he was a pure mathematician, interested in the theory of groups, matrices and operators, but he had great facility in many branches of mathematics. His book on "Quantenmechanik", published in 1932, was a notable exposition of the mathematical logic of the theory. Another book, "The Theory of Grmes and Economic Behaviour", written in collaboration with the distinguished economist, Oskar Morgenstern, and first published in 1944, gave von Neumann the opportunity to display his powers in combinatory analysis.

When the scientific strength of the United States was being mobilized in the Second World War, von Neumann soon played a prominent part. He began to work on the motion of compressible fluids caused by explosions. He gave the solution of the point source explosion, obtained independently by $G$. I. Taylor, and he made important contributions to the theories of detonation and of the motion of the triple point in air blast. After only a few months, this great pure mathematician was discussing and planning experiments with his new colleagues, and his suggestions always commanded attention.

As soon as scientific work began at Los Alamos, von Neumann was brought in as a consultant. For the rest of his life, he paid frequent visits to Los Alamos and fow had such a decisive influence as he. At Los Alamos, von Neumann realized from the start the importance of machine calculation, and his interest in electronic digital computers received an impetus which lasted through the post-war years. With several collaborators, he went deeply into the mathematical logic of the computers, and even though the machine built under his guidance at the Institute for Advanced Study at Princeton was sur. passed by other machines in the United States, von Neumann continued to be one of the leaders of thought on such machines.

The United States Atomic Energy Commission found him to be one of its most valuable consultants. He served on the General Advisory Committee and he continued to play a leading part among all the consultants in influencing the scientific work of the Commission. Finally, in 1955, he became a com. missioner.

His tragic death on February 8 at the early age of fifty-four is a grievous loss to American science. Like Enrico Fermi, he was a victim of cancer. He is deeply mourned by many, and those who knew him will never forget his brilliance, his common sense, his loyalty and his sense of humour.

\section{W. G. Penney}

\section{The Marchese Solari}

The Marchese Luigi Solari, an early associate and life-long friend of Marconi, died in Rome on February 6 at the age of eighty-three after a long illness.

As an officer of the Italian Navy, the Marchese Solari was associated with Marconi's early demonstrations of wireless telegraphy on board Italian warships in 1897, and the two men became close friends. When the Italian Government put the warship Carlo Alberto at Marconi's disposal in 1902 for the furtherance of his investigations into the propagation of wireless waves, the Marchese Solari accompanied Marconi as the officer in charge of the vessel's wireless telegraph station.

Shortly after his retirement from the Navy he became manager of the Italian branch of Marconi's 